\title{
Extent of soil sodification as influenced by different irrigation water sources in a typical black soil of Karnataka
}

\section{S. KIRANKUMAR, M.S. NAGARAJA, R. SUMAAND ASHOK S. ALUR}

Received : 07.11.2014; Accepted : 25.05.2015

\section{MEMBERS OF RESEARCH FORUM:}

Corresponding author : S. KIRANKUMAR, Department of Soil Science and Agricultural Chemistry, College of Horticulture, University of Horticultural Sciences, BAGALKOT (KARNATAKA) INDIA

Email: kiruhorti@gmail.com

Co-authors :

M.S. NAGARAJA, R. SUMA AND ASHOK S. ALUR, Department of Soil Science and Agricultural Chemistry, College of Horticulture, University of Horticultural Sciences, BAGALKOT (KARNATAKA) INDIA

\begin{abstract}
Summary
An extensive survey was carried out to study the effect of irrigation water on soil sodification, in terms of soil sodium adsorption ratio (SAR) and residual sodium carbonate (RSC), in a typical black soil of Karnataka and it was carried out in Mudhol taluka of Bagalkot district. The soil SAR and RSC varied greatly up on different sources of irrigation water. The values of SAR ranged from 0.79 in borewell irrigated soils to 18.43 in lift irrigated soils. Most of the studied soils (131 samples) were found to be safe from sodicity hazard with $<10$ SAR values. In terms of RSC of soils ranged from $-23.20 \mathrm{meq} / \mathrm{l}$ in lift irrigated soils to $+11.70 \mathrm{meq} / \mathrm{l}$ in dryland soils. Majority of the black soils of Mudhol taluka (70.6\%; 101 samples) were found safe with low RSC values $(<1.25$ meq/l) while, 23.8 per cent of the samples recorded higher RSC of $>2.5$ meq/l.
\end{abstract}

Key words : Black soil, Sodium adsorption ratio, Residual sodium carbonate, Lift irrigation, Sodicity hazard

How to cite this article : Kirankumar, S., Nagaraja, M.S., Suma, R. and Alur, Ashok S. (2015). Extent of soil sodification as influenced by different irrigation water sources in a typical black soil of Karnataka. Asian J. Soil Sci., 10(1) : 154-157. 